Biotechnology Research
Available online at http://zjar.journals.ekb.eg
http:/www.journals.zu.edu.eg/journalDisplay.aspx?Journalld=1\&queryType=Master

\title{
CHARACTERIZATION OF BIODIESEL PREPARED FROM WASTE COOKING OIL
}

\author{
Mai A.I. Kurdi, M.Z. Sitohy, H.T. Hefnawy ${ }^{*}$ and A.M. Gomaa
}

Agric. Bioch. Dept., Fac. Agric., Zagazig Univ., Egypt

Received: 19/11/2020 ; Accepted: 21/02/2021

\begin{abstract}
Increased energy consumption and the depletion of petroleum reserves have pushed up oil prices globally. Diminishing the petroleum reserve is another global risk factor. Producing Biodiesel vegetable oils and animal fat by transesterification can be a considerable energy alternative. In this study, biodiesel is produced from waste cooking oil by transesterification method with methanol in the presence of $\mathrm{HCl}$ as a catalyst. Biodiesel production begins with mixing raw the collected used cooking oil into one pool. The mixture is then settled for 8 hours at room temperature before initiating the transesterification process $90^{\circ} \mathrm{C}$ by mixing $\mathrm{HCl}(1 \%$ of oil weight) with methanol, while the methanol: oil ratio is 1:4. The process lasts for $9 \mathrm{~h}$ under a condenser. Biodiesel purification is carried out by washing the product twice with hot water (temperature $70^{\circ} \mathrm{C}$ ) to remove excess reactants and byproducts such as alcohol, catalysts, soap and glycerine, and fatty acid methyl ester (FAME). The resulting diesel density of $3.72 \mathrm{~kg} / \mathrm{m}$ (at $15^{\circ} \mathrm{C}$ ), a kinematic viscosity of $8.93 \mathrm{~mm} / \mathrm{sec}$., at $40^{\circ} \mathrm{C}$, calorific value was $41299 \mathrm{kj} / \mathrm{kg}$, Total acid number of 0.111 was for waste cooking oil, Cetane number of 48.95, acid value (AV) was $1.135 \mathrm{mg} / \mathrm{koh}$ was and Ester value (EV) was $178.42 \mathrm{mg} / \mathrm{koh}$. The Saponification value (SV) was $179.56 \mathrm{mg} / \mathrm{koh}, \mathrm{pH}$ was 5.7, and Glycerol Weight was $97.53(\mathrm{Gw})$.
\end{abstract}

Key words: Biodiesel, preparation, fuel properties, transesterification,GLC

\section{INTRODUCTION}

Biodiesel, an alternative fuel adequate for internal combustion engines, is produced by transesterification of vegetable oil (sunflower oil, rapeseed oil, soybean oil, palm oil, oil from exotic plant species) or animal fat into fatty acid methyl esters (FAME). Biodiesel is clear, flammable liquid free of impurities. It is waterinsoluble with yellow color (Malovcov, 2013). Biodiesel is reported, non-toxic, biodegradable and environmentally safe (Eevera, 2009). According to current standards, transesterification of vegetable oils with alcohol into methyl esters is the most accepted method to meet the requirements of EN 14214 standard for biodiesel production (Talebian-Kiakalaieh, 2013). The biodiesel transesterification process separates the fatty acids from the glycerol base, producing free esters, either with or without using a catalyst (Eevera, 2009; Malovcova, 2013). The utilization of different types of catalysts improves the rate and yield of biodiesel. Many different alcohols can be used in this reaction, including methanol, ethanol, propanol, and butanol. The methanol application is more feasible because of its low-cost and physical, besides its chemical advantages, such as high polarity and the shortest alcohol chain. According to Fig. 1, R1, R2 and R3 are long chains of hydrocarbons called fatty acid chains. In this reaction on one mole of triglyceride reacting reacts with three moles of methanol to produce three moles methyl ester (biodiesel) and one-mole glycerol (Malovcova, 2013; TalebianKiakalaieh, 2013).

\footnotetext{
* Corresponding author: Tel. : +201028377005

E-mail address: hefnawytaha2014@ygmail.com
} 
<smiles>[R3]C(=O)OCI(I)C(I)OC([R16])=O</smiles>

(Triglycerides)<smiles>[R]C(=O)OC</smiles>

(Mixture of fatty esters) (Glycerol)

Fig. 1. Methanolysis of triglyceride

Generally, the transesterification reaction involves some critical parameters, significantly influencing the final conversion rate and yield. The essential variables are reaction temperature and time, the oil free fatty acid content and water content, type and mount of catalyst, the molar ratio of alcohol to oil, the type of chemical stream of alcohol, and the use of cosolvent and mixing intensity (TalebianKiakalaieh, 2013). The majority of the world's energy needs are supplied through petrochemical sources, coal and natural gases, apart from hydroelectricity and nuclear energy. All these sources are finite will be consumed shortly at the current usage rates (Srivastava and Prasad, 2000). Diesel fuels have an essential function in a developed country's industrial economy and are currently being used in transports, industrial and agricultural goods. The world demand for diesel fuels increases to compensate for the shortage in petroleum products and commensurate the increasing demands in national and international transport. This trend has stimulated the recent interest in alternative sources for petroleum-based fuels. An alternative fuel should be easily available, environment friendly and techno-economically competitive. One starting material of such feuls is triglycerides and their derivatives. Being renewable, widely available from a variety of sources and having low sulphur contents close to zero, and hence causing least environmental damage, vegetable oils are a good choice for biodiesel production. Chemically the oils consist of triglyceride molecules of three long-chain fatty acids, that are ester bonded to a single glycerol molecule. These fatty asids differ by the length of the carbon chain, orientation and position of double bonds in these chain. Thus biodiesel refers to lower alkyl esters of long-chain fatty asids, which are synthesized either by transesterification with lower alcohols or by esterification of fatty acids. This work aims to test the feasibility of producing biodiesel from waste vegetable oils by transesterification with methanol in the presence of an alkaline catalyst $(\mathrm{KOH})$ and evaluate the produced physicochemical characteristics methyl esters fuel.

\section{MATERIALS AND METHODS}

\section{Materials}

The waste cooking oil obtained from restaurants in Zagazig city, Sharkia Governorate, Egypt nHexane, methanol, sodium methoxide, sodium hydroxide, potassium hydroxids, potassium methoxide and anhydrous sodium sulfate were purchased from Merck chemical co.. Pure fatty acid esters, used as standards, were procured from Sigma chemical co. All the chemicals used were of analytical grade.

\section{Transesterification of Waste Cooking Oil}

In a one liter 3-neck round bottom flask, 100 $\mathrm{ml}$ of Egyptian linseed and waste cooking oil $(50 \mathrm{~g})$ were heated and stirred in a water bath equipped with magnetic stirrer (1000 rpm) adjusted at $20-65^{\circ} \mathrm{C}$. $\mathrm{KOH}$ was added to 
methanol at a dry weight ratio of $0.3-2 \%$ by weight of oil and molecular ratio of 3:1-10:1). in a separate flask and carefully shake till $\mathrm{KOH}$ became completely soluble in methanol (methoxide is formed). Methoxide was added to the heated oil $\left(90^{\circ} \mathrm{C}\right)$. The product was left in a separating funnel for 12 hours and then the ester layer was collected after complete separation by washing with hot water for 56 times, using anhydrous $\mathrm{Na}_{2} \mathrm{SO}_{4}$ according to (Abdel Fatah et al., 2012).

\section{Fatty Ester Profile by Gas Chromatography (GC)}

Fatty acid methyl esters (FAME) were separated using a Varian (Walnut Creek, CA, USA) 8400 gas chromatograph (GC) equipped with a flame ionization (FID) detector and SP2380 (Supelco, Bellefonte, PA, USA) column (30 m $40.25 \mathrm{~mm}$ i.d., $0.20 \mu \mathrm{m}$ film thickness). Carrier gas was heat $1 \mathrm{~mL} / \mathrm{min}$. The oven temperature was held at $150^{\circ} \mathrm{C}$ for $15 \mathrm{~min}$, increased to $210^{\circ} \mathrm{C}$ at $2^{\circ} \mathrm{C} / \mathrm{min}$, followed by an increase to $220^{\circ} \mathrm{C}$ at $50^{\circ} \mathrm{C} / \mathrm{min}$. The injector and detector temperatures were $240^{\circ} \mathrm{C}$ and $270^{\circ} \mathrm{C}$, respectively. FAME peaks were identified by comparison with the retention times of known reference standards. Each FAME determination was run in triplicate and average values were calculated.

\section{Physical and Chemical Properties of Investigated Oils}

\section{Determination of density}

Density was measured using the standard method according to AOAC method (1995).

\section{Determination of kinematic viscosity}

Kinematic viscosity $(v$, in square millimeters per second) was determined with CannonFenske viscometers CT-1000 (Cannon Instrument, State College, PA, USA) at $40^{\circ} \mathrm{C}$ according to Knothe and Steidler (2005). All experiments were run in triplicate and the mean values were calculated.

\section{Determination of flash point}

The flash point of sample was measured using the standard method according to AOAC (1995).

\section{Determination of cloud point}

The cloud point was determined as the temperature at which the sample begins to haze following AOAC (1995).

\section{Determination of pour point}

The pour point was determined according to ASTM D.97 method (Kywe and Oo, 2009).

\section{Determination of acid value}

Acid value of the oil was determined according to AOAC (1995).

Determination of iodine value

The iodine value was determined using the Hanus method as described in AOAC (1995).

\section{RESULTS AND DISCUSSION}

\section{Fatty Acid Composition}

Data in Table 1 show the main fatty acid (FA) found in waste cooking oil. Linoleic acid (C18:2, 26.1\%) was the major FA followed by oleic $(\mathrm{C} 18: 1,20.5 \%)$. Other minor fatty acid included palmitic acid (C16:0, 12.8\%), and stearic acid $(\mathrm{C} 18: 0,2.2 \%)$. This result is in agreement with previously reported data (Savita et al., 2012).

\section{Physical and Chemical properties of Investigated Oils}

\section{Density}

Bio-diesel fuels are, in general, characterized by higher density than conventional petroleum diesel, which means that volumetricallyoperating fuel pumps will inject greater mass of biodiesel than conventional diesel fuel. This in turn will affect the air-fuel ratio hence the local gas temperatures and NOx emissions, as long as the engine retains its diesel-fuel calibration. Actually, it has been argued that lower diesel densities favor lower NOx (McCormick $\boldsymbol{e t}$ al., 2001), although other researchers have not confirmed such an unequivocal trend. As shown in Table 2. The (average) densities of the waste cooking oil was $3.72 \mathrm{~kg} / \mathrm{m}^{3}$, with the overall average value being $880.2 \mathrm{~kg} / \mathrm{m}^{3}$. In the United States, there is no specification for biodiesel density. In European countires on the other hand, the acceptable range is quite wide (860$900 \mathrm{~kg} / \mathrm{m}^{3}$ ), and this is met by all examined methyl esters acceptable. 
Table 1. Levels of fatty acid percentage in waste cooing oil methyl ester

\begin{tabular}{lcc}
\hline Fatty acid & Structure & Percentage \\
\hline Capric acid & $\mathrm{C} 10: 0$ & 3.9 \\
Lauric acid & $\mathrm{C} 12: 0$ & 11.8 \\
Myristic acid & $\mathrm{C} 14: 0$ & 9 \\
Palmitic acid & $\mathrm{C} 16: 0$ & 12.8 \\
Palmitoleic acid & $\mathrm{C} 16: 1$ & 0.10 \\
Stearic acid & $\mathrm{C} 18: 0$ & 2.2 \\
Oleic acid & $\mathrm{C} 18: 1$ & 20.5 \\
Linoleic acid & $\mathrm{C} 18: 2$ & 26.1 \\
Linolenic acid & $\mathrm{C} 18: 3$ & 0.88 \\
Arachidic acid & $\mathrm{C} 20: 0$ & 0.09 \\
Behenic acid & $\mathrm{C} 22: 0$ & 0.10 \\
\hline
\end{tabular}

Table 2. Phsical and Chemical Properties of Biodesel Waste Cooking Oil

\begin{tabular}{lcc}
\hline Properties & Waste cooking oil & Biodiesel \\
\hline Calorific value, kjlkg & 3024 & 41299 \\
Total Acid number & 1.135 & 0.111 \\
Cetane Number & 22.54 & 48.95 \\
Density $\left(\mathbf{k g} / \mathbf{m}^{3}\right)$ & 3.72 & 880 \\
Viscosity $\left(\mathbf{m m}^{2} / \mathbf{s e c}\right)$ & 8.93 & 3.8 \\
Saponification value & 179.56 & 190 \\
Ester value & 178.42 & 180 \\
pH & 5.7 & 5.3 \\
The percentage of acidity & 5.70 & 0.45 \\
Glycerol Weight & 97.53 & 0.0 \\
Cloud point $\left({ }^{\circ} \mathbf{C}\right)$ & 310 & -13 \\
pour point $\left({ }^{\circ} \mathbf{C}\right)$ & & -24 \\
Acid value & 0.11 & 1.37 \\
Iodine value & 120 & 2.21 \\
\hline
\end{tabular}




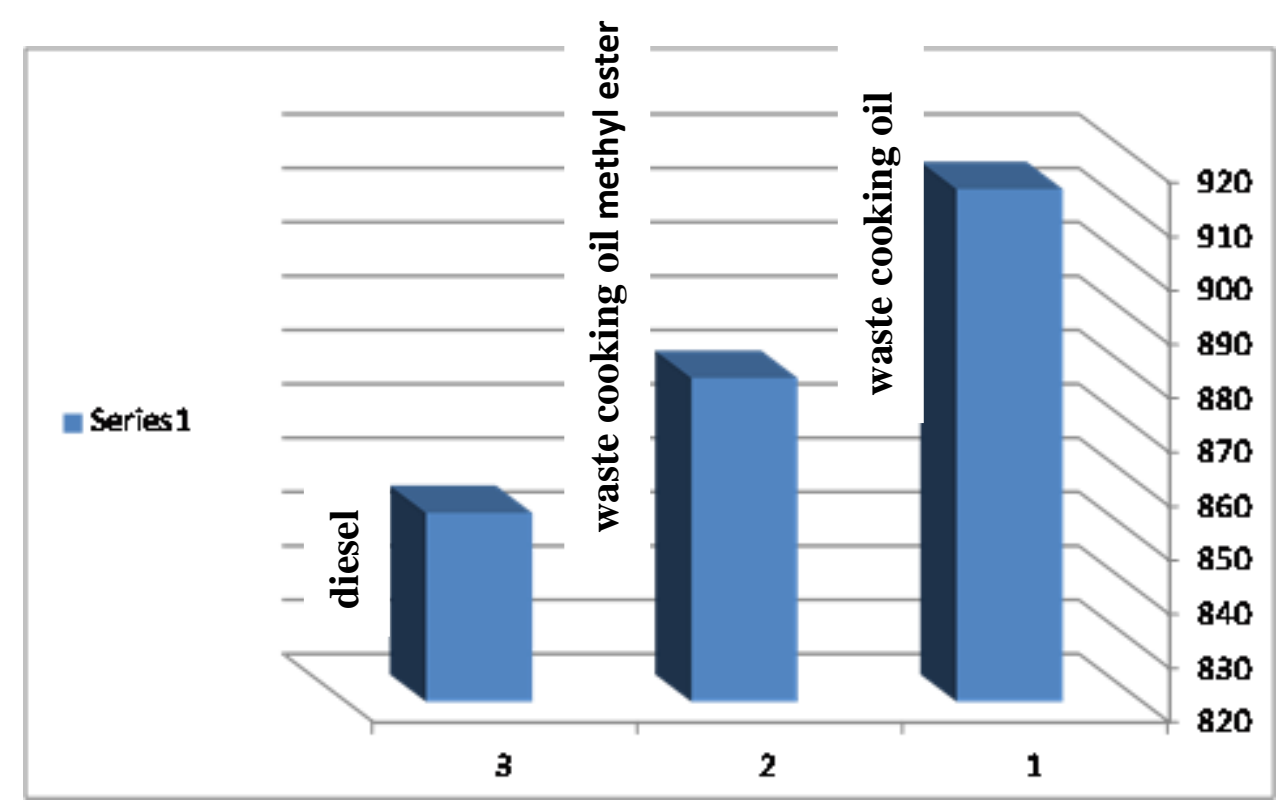

Fig. 2. Density $\left(\mathrm{kg} / \mathrm{m}^{3}\right)$ of investigated oils

\section{Kinematic viscosity}

Viscosity is a measure of the resistance of a fluid which is deformed by either shear or tensile stress. In the case of liquid fuels, the less viscous the fluid is, the greater its ease of movement (fluidity) (Rakopoulos et al., 2006). Vegetable oils have higher viscosities than the acceptable diesel fuel values. Thus, they cannot be used safely as fuels in a compression ignition engine, at least without prior heating to decreases viscosity. On the other hand, the transesterification process reduces the FAME's viscosity to levels comparable to but still slightly higher than that of petrodiesel. As shown in Table 2 the viscosity values of the waste cooking oil was $8.93\left(\mathrm{~mm}^{2} /\right.$ sec.), and was reduced to 3.8 after the transesterification.

\section{Flash point}

The flash point (FP) is a measure of the temperature to which a fuel must be heated such that the mixture of vapor and air above the fuel gets ignited; FP varies inversely with the fuel's volatility. As documented in Table 2, storage of neat bio-diesel is thus much safer than diesel in this regard (Tsegay, 2017). Specifically, the (average) values of flash point for waste cooking oil methyl ester was $65^{\circ} \mathrm{C}$. European specifications require bio-diesel fuels to have at least $101^{\circ} \mathrm{C}$ flash point, whereas in the US the minimum required level is lower $\left(93^{\circ} \mathrm{C}\right)$; Although flash point depends, in general, on the originating oil, it is not directly linked to the fatty acid composition (Berman et al., 2011).

\section{Cloud point and pour point}

Biodiesel has higher cloud and pour points than conventional diesel fuel (Fernando $\boldsymbol{e t}$ al., 2007; Sanford et al., 2011). Table 2 tillustrates that waste cooking oil has relatively a high cloud point $-13^{\circ} \mathrm{C}$, while the derived biodiesel has a higly reduced point $\left(-24^{\circ} \mathrm{C}\right)$.

\section{Acid value (AV)}

The AV of waste cooking oil and its prepared methyl esters was higher, (Table 2) most of the FFA had been removed. In the case of waste cooking oil, the AV was 0.111, while in the case of waste cooking oil methyl esters, it was 1.37. These data agreed with Shailesh $\boldsymbol{e t}$ al. (2010), who stated that the acid value of waste cooking oil methyl ester was in the same range.

\section{Iodine value}

The iodine value is a parameter used to determine the degree of unsaturation in a vegetable oil or animal fat. This number indicates the mass of iodine $\left(\mathrm{I}_{2}\right)$ in grams that is necessary to completely saturate, by means of a 
stoichiometric reaction, the molecules of $100 \mathrm{~g}$ of a given oil (Lapuerta et al., 2009). Table 2 illustrates the iodine values of the examined biodiesels oils. It was 108 for the waste cooking oil methyl ester. There is no specification in the US for the Iodine value, whereas European specifications require that bio-diesels used in compression ignition engines have a (rather low) maximum value of Iodine value of the order of 120. The idea behind this specification is that, high fuel iodine values indicate propensity for polymerization resulting in deposit formation (Graboski and McCormick, 1998). This means that investigated on the other hand waste cooking oil methyl ester is accepted.

\section{REFERENCES}

Abdel Fatah, M., H.A. Farag and M.E. Ossman (2012). Production of bio-diesel from nonedible oil and effect of blending with diesel on fuel properties. Engin. Sci. and Technol. An Int. J., 2(4) 2250-3498.

AOAC (1995). Official Methods of Analysis of Assocation of Official Agriculture Chemists, published by the AOAC, $16^{\text {th }}$ Ed. Washington DC.

Berman, P., S. Nizri and Z. Wiesman (2011). Castor oil bio-diesel and its blends as alternative fuel. Biomass and Bio-Energy, 35: 2861-2866.

Eevera, T. (2009). Biodiesel production process optimization and characterization to assess the suitability of the product for varied environmental conditions. In Renewable Energy, 34 (3): 762-765.

Fernando, S., P. Karra, R. Hernandez and S.K. Jha (2007). Effect of incompletely converted soybean oil on bio-diesel quality. Ener., 32: 844-851.

Graboski, M.S. and R.L. McCormick (1998). Combustion of fat and vegetable oil derived fuels in diesel engines. Prog. Energ. Combust Sci., 24:125-164.

Knothe, G. and K.R. Steidler (2005). Kinematic viscosity of bio-diesel fuel components and related compounds. Influence of compound structure and comparison to petrodiesel fuel components. Fuel, 84: 1059-1065.
Kywe, T. and M.M. Oo (2009). Production of bio-diesel from jatropha oil in pilot plant. World Acad. Sci., Engin. and Technol., 50: 477-483

Lapuerta, M., J. Rodriguez-Fernandez and E.F. deMora (2009). Correlation for the estimation of the cetane number of bio-diesel fuels and implications on the iodine number. Ener. Policy, 37:4337-4344.

Malovcova, L. (2013). Utilization of oily raw materials for biodiesel production. [Graduate Theses]- Slovak Univ. Technol. Bratislava. Fac. Materials Sci. and Technol., Inst. Safety and Environ. Eng. Trnava, 86 - 92.

McCormick, R.L., M.S. Graboski, T.L. Alleman and A.M. Herring (2001). Impact of biodiesel source material and chemical structure on emissions of criteria pollutants from a heavy-duty engine. Environ. Sci. Technol., 35: 1742-1747.

Rakopoulos, C.D., K.A. Antonopoulos, D.C. Rakopoulos, D.T. Hountalas and E.G. Giakoumis (2006). Comparative performance and emissions study of a direct injection diesel engine using blends of diesel fuel with vegetable oils or bio-diesels of various origins. Energ. Convers Manag., 47:3272-3287.

Sanford, S., J. White, P. Shah, C. Wee, M. Valverde and G. Meier (2011). Feedstock and bio-diesel characteristics report. http:// www. regfuel. com $/ \mathrm{pdfs} /$ Feedstock and Bio-diesel Characteristics Report. pdf. Thesis.

Savita, D., S. Kanakraj and A. Rehman (2012). Linseed oil as a potential resource for biodiesel a review. Renewable and Sustainable Ener. Rev., 4415- 4421.

Shailesh, N., S. Brajendra, K. Sharma, B.R. Moser and S.Z. Erhan (2010). Preparation and evaluation of wastwaste cooking oil oil methyl esters as bio-diesel and as a blend component in ultra-low sulfur diesel fuel. Bio. Ener. Res., 3: 214-223.

Srivastava, A. and R. Prasad (2000). Triglyceridesbased diesel fuels. Renewable and Sustainable Ener. Rev.,4:111-133.

Talebian-Kiakalaieh, A. (2013). A review on novel processes of biodiesel production from 
waste cooking oil. In Appl. Energy, 104: 683-710.

Tsegay, H. (2017). Determination of oil and biodiesel content, physicochemical properties of the oil extracted from avocado seed (Persea Americana) grown in Wonago and Dilla (Gedeo zone), Southern Ethiopia. Chem. Int., 3 (3): 311.

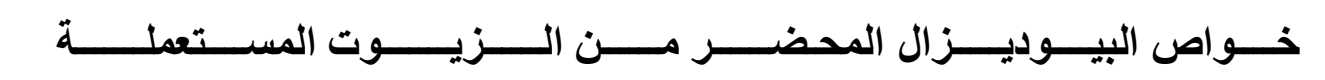

مي عبدالله إبراهيم كردي- محمود زكي سطوحي - حفناوي طه حفناوي- أيمن محمد السيد جمعه

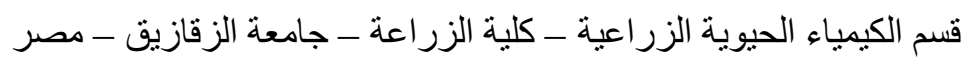

أدى استهلاك الطاقة المتزايدة الي نضوب الاحتياطيات النفطية الي ارتفاع اسعار النفط في العالم ويعد تناقص احتباطي

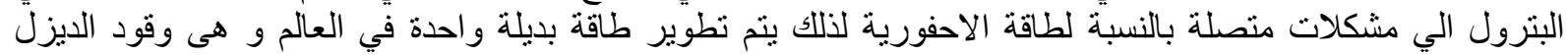

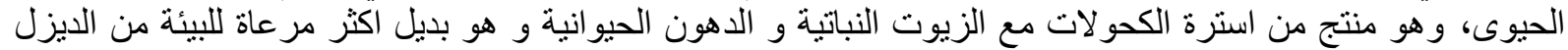

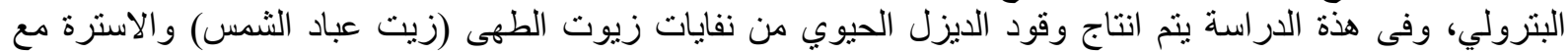

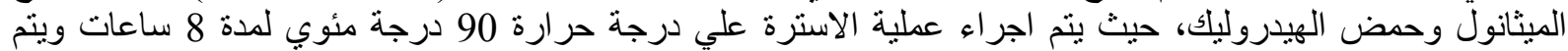

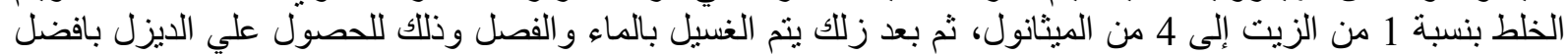

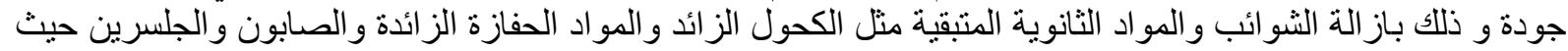

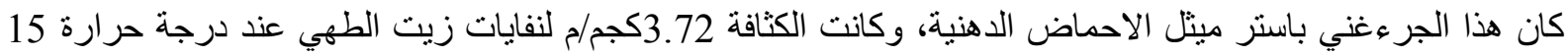

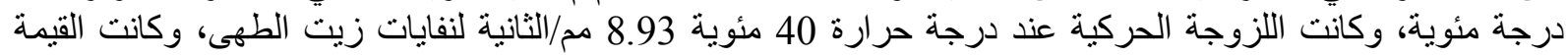

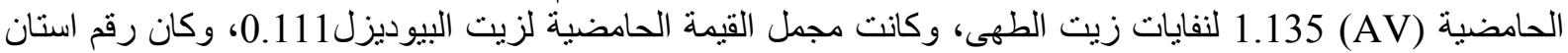

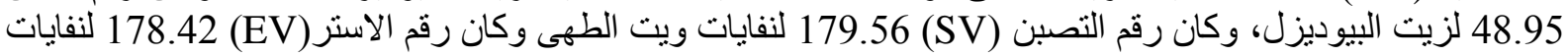

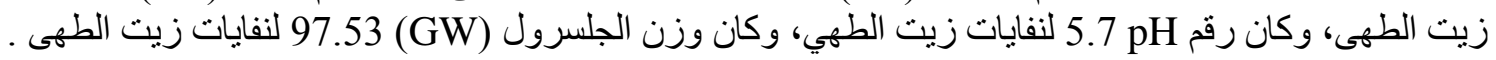

أستاذ الكيمياء الحيوية - المركز القومي للبحوث. المئ.

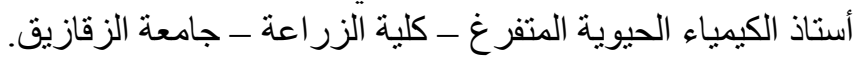

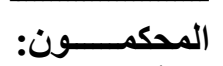

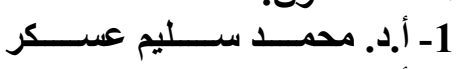

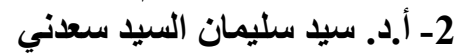

